\title{
Nonformal Education Ideas on Mahakam Ulu Community as The Extension Area of West Kutai District
}

\author{
Gunarti Dwi Lestari \\ Non Formal Education Department, State University of Surabaya \\ tarie_henry@yahoo.co.id
}

\begin{abstract}
Non-formal education as part of the educational system has the same task with the formal education that provides the best service to society have targeted non-formal education. Target non-formal education is increasingly widespread that not only relate to the poor and the stupid (retarded, elementary education illiterate, drop out of formal education), but targets non-formal education continues to escalate in accordance with the development of science and technology as well as employment and culture itself. As the objectives, the program / non-formal education activities should continue to be expanded according to the needs and conditions of the society development. Research activity on Non-formal Education in the Mahakam Ulu Regency uses descriptive quantitative approach, with the survey method. The used data are primary data and secondary data. The results of this work show that the study of non-formal education aimed at two important things: (1) the study of non-formal education itself (internal review), this study relate to: the study of the curriculum (Non Formal Education program), models of Non Formal Education program, Non Formal Education program objectives, the Non Formal Education program's existence (roles and functions) in the middle of Mahakam Ulu community as an extension area of West Kutai area. (2) Non-formal education concerning to the views Mahakam Ulu communities and governments for Non Formal Education programs (recognition), this study can be referred to as external review.
\end{abstract}

\section{Keywords - Ideas, Nonformal Education}

\section{INTRODUCTION}

Non-formal education as part of the education system has the same task with the formal education that provides the best service to society especially non-formal education. Non-formal education target is increasingly widespread that not only relate to the poor and the stupid (retarded, elementary education illiterate, drop out of formal education), but targets non-formal education continues to escalate in accordance with the development of science and as well as employment and culture society itself. As these objectives, the program / non-formal education

Activities should continue to be expanded according to the needs and conditions of the society development. In principle, the expansion of the activity/ non-formal education programs should be in line with the new thinking on the learning concept (learning), where learning is impressed not only take place in schools (formal) not become priority and begin to move on formal education setting. Learning should be viewed the same as the 'living, and living itself is a process of problem finding and problem solving'. We must learn from everything we do, we must exploit every experience as a learning experience. Every institution in our community-government on nongovernment agencies, stores, recreational places, organizations, churches, mosques, fields, factories, cooperatives, associations, and the like becomes resources for learning, as does every person we access to parent, child, friend, service, provider, doctor, teacher, fellow worker, supervisor, minister, store clerk, and so on and on. Learning means making use every resourcesin or out of educational institutions-for our personal growth and development. Even the word is regarded as a classroom. [1]

Change, development and expansion of non-formal education provides an appreciation and new ideas to the ways of non-formal education in providing education for the people, especially adults, Both for those who do not have access to formal education and those who had formal education but inadequate and irrelevant with life and the evolving situation in the environment (society).

The development process requires the participation of millions of educated adults, while the existing formal education institutions are not able to access the educational problems in the society. In certain areas of some residents found that schooling education system is not able to equip the skills they need to compete and gambling in a technological society [2]

The education process that expands from the structured formal system, into a new configuration system of chain thought and experiences which are separated and widened, and other types of meetings by utilizing the facilities available. The role of non-formal education as a complement, supplement, or substitute formal education is a configuration that is contextual-based and life-relevant; so as to realize the program / non-formal education activities which are strategic and functional for the community.

The people concept of lifelong learning as a master concept encourages individuals, institutions, associations, community care education or other entity to participate in developing a new way of thinking in responding to the challenges of the new needs of the community about education and learning. School as a formal program will no longer be the only place and monopolize education (formal) schooling and business agencies no longer take care only financial, but start to 
participate in education, especially non-formal education. The birth of new educational organizations and educational institutions without the label in addition, extension and other opportunities and facilities to the community to learn themselves. So it becomes 'self-supporting organization' to contribute non-formal education development.

There are some society roles in certain communities in nonformal education: People participate in developing Community Learning Center, Studio Activity Learning, Internships, Business Productive, Religious Education in the form of pesantren where provide to the students not only in the form of religious education but also public education, and entrepreneurial skills as the provision of life skill and living in the in education community, also known as 'learning society'. Similarly, education provision and skills related to working skill (agriculture, fisheries, and households industry).

The creation of a society like to learn (learning society) gives a new environment and spirit of education in society, this condition is observed as a concrete manifestation of lifelong education model. The climate promoting opportunity every person, organization and social institutions, industry and the wider community to learn; the growth of the spirit and motivation to learn independently (independent learning) to meet the lifelong needs, and strengthen education empowering (educability) of people in order to have self-education and in the society, are the positive side of the concepts underlying the non-formal education.

The creation of a society likes to learn can create a variety of non-formal education opportunities in an accessible place and appropriate ways suitable with the society's potential, skills and proficiency. Educability Meta concept enables community (learners) 'fully-able to take advantage of any available educational opportunities', is actively looking for new information relating to the interests of his life.

\section{METHOD}

Study on Non-formal Education in the Mahakam Ulu Regency uses descriptive quantitative approach, with the survey method in the process of data acquisition. The data used are primary data and secondary data. Descriptive study is a study to determine the value of an independent variable, either one or more variables, without making comparisons or linking to other variables [3]. Descriptive study is an analysis of the problems in the form of recent facts from a population as it is. This type of research is generally associated with an opinion (individual, group, or organization), event or procedure [4].

Compilation stages and data analysis in this activity are as follows. Data compilation activities include: grouping the data, verify the data that has been collected, Calculating Data, data processing (tabulation, graphs and formulas). While the analysis stage is the evaluation and assessment stage of data and information that is obtained based on the approaches, principles, methods and techniques of analysis in accordance with the results / output needed.

\section{RESULTS AND DISCUSSION}

Mahakam Ulu district with the capital Ujoh Bilang is a district extension of Kutai Barat where has been established based UU.Nomor 2 Year 2013. With an area of about 15.315 $\mathrm{km} 2$, or approximately 7.26 percent of the East Kalimantan province, Mahakam Ulu regency is geographically located between 113048'49', until 115045'49' East longitude and between $1^{0} 31^{\prime} 05^{\prime}$ ' North longitude and $0^{0} 09^{\prime} 00^{\prime}$ ' South longitude.

- The Mahakam Ulu District border is

- Malinau District and the Sarawak State (East Malaysia) in the north,

- Kutai regency in the east,

- Kutai West District and Central Kalimantan Province in the south and

- The western side bordering the province of Central Kalimantan and West Kalimantan Province.

Mahakam Ulu district is divided into 5 sub districts and 49 Kampung. The five sub District are Long Hubung, Laham, Long Bagun, Long Pahangai, Long Apari.The details can be seen in the following table

TABLE I. POSITION AND SUB DISTRICT SQUARE

\begin{tabular}{|c|c|}
\hline SUB DISTRICT & SQUARE $\left(\mathbf{K M}^{\mathbf{2}}\right)$ \\
\hline 1. Long Hubung & 530,90 \\
\hline 2. Laham & 901,80 \\
\hline 3. Long Bagun & $4.971,20$ \\
\hline 4. Long Pahangai & $3.420,40$ \\
\hline 5. Long Apari & $5.490,70$ \\
\hline
\end{tabular}

Source: Mahakam Ulu Regional Development Planning Agency

Formal education is a process that is tiered from the primary level to university. To support the success of development in the field of education, formal education is commonly operated in schools not only supervised by the Education and Culture Ministry, but some are supervised other ministry such as the Ministry of Religious Affairs, Ministry of Health, Ministry of Social Affairs and others.

Based on data from the Department of Education and culture in Mahakam Ulu district is known that the number of schools from elementary school to high school, both public and private in 2012, there were 56 schools consists 38 schools for primary schools, 10 schools for secondary schools and 8 school level Senior High School / Vocational High School.

Beside the number of schools and students, other factors need to be considered in the education quality is the number of teachers. The number of teachers from elementary to high school / vocational both public and private registered in the Education and Culture Ministry in Mahakam Ulu district as 525 where 365 teachers are primary school teachers, 103 are 
secondary school teachers and 57 are Senior High School / Vocational High School teachers.

Comparison or ratio between teachers and students will describe the student burden that must be encountered by a teacher in learning. Enrolled teachers in the Mahakam Ulu district for all levels of education are enough although in high school the teacher burden is relatively heavier when compared with lower levels of education.

Based on these data, the formal education which was performed at the Mahakam Ulu district cannot fully serve the needs especially skill areas. Therefore, people need to get the services of non-formal education as a complement, an addition or a substitute for formal education.

The importance of the implementation of non-formal education in accordance with the conditions and the concept of non-formal education learning in society, so the five basic strategies that need to be developed are:

- Humanistic approach, the community is seen as the subject of development. Community must be admitted as the potential to grow and grown and to be able to develop themselves.

- Participatory approach implies that the public, the concerned institutions, and or communities will be involved in the management and execution of community development.

- Collaborative approach, in community development need for cooperation with other parties (integrated) and coordinated and synergies.

- Continuation approach community development is performed continuously, so cadre coaching from the community is the most fundamental.

- Cultural approach, appreciation of culture and customs, culture that grow in society and in development community are things that need attention. [5]

With five strategies, then the non-formal education as what the community needs in terms of non-formal education program that is able to touch and change people to be better living which are characterized by increased income (economic), awareness of the social environment or society know and understand how to build themselves.

Referring the principles and basic strategies it is important that non-formal education be considered in the context of its role in the community are:

- Develop non-formal education programs which are able to develop the community, so they have a adaptability, flexibility, innovation and entrepreneurial attitudes and aptitudes.

- Develop educational programs that can change rural and urban poverty (rural and urban community development), both through vocational education programs and other types of educational programs able to cover a real need in the society life (feet needs).
- Find and identify problems that can be made or solved through the roles and tasks from non-formal education significantly while maintaining the originality of the principles of community development by and for the community itself.

- Develop non-formal education programs which are completely new, innovative and low cost.

Based on the roles of non-formal education and basic strategy of development in the society, the study of non-formal education is directed at the two thing at first, the study of nonformal education itself (internal review), this study relate to: studies curriculum (Non Formal Education program), Non Formal Education program models, Non Formal Education program target, the Non Formal Education program existence (roles and functions) in the society etc. The second study of non-formal education relates to the society views and government towards Non Formal Education programs (recognition), this study can be referred to external review. This study is important because people are not only directed as non-formal education target but society is seen as the actors (learning resources) of non-formal education. While the government expectations only concerns with establishment especially that what is implemented on governance policies built to the existence of non-formal education in the society.

Ideas that can be realized for implementing non-formal education program in accordance with the conditions of Mahakam Ulu culture is the equality program equipped with life skillbased community characteristics and it will be followed up with a needs assessment or activities based on the society needs.

\section{CONCLUSIONS}

The role of non-formal education as a complement, supplement, or substitute formal education is a configuration that is contextual-based and life-relevant, so it is able to realize strategic and functional the non-formal education program activities for people Mahakam Ulu.

\section{ACKNOWLEDGMENT}

The authors would like to thank the Bappeda Mahakam Ulu which has cooperated with University of Surabaya in this research.

\section{REFERENCES}

[1] Knowles, Malcom. 1980. The Modern Practice of Adult Education. Chicago: Association Press

[2] Kamil, Mustofa. 2009. Pendidikan Non Formal. Bandung: Alfabeta.

[3] Sugiyono. 2009. Metode Penelitian Kuantitatif, Kualitatif dan R\&D. Bandung: Alfabet

[4] Sukmadinata. 2006. Metode Penelitian Pendidikan. Bandung: Rosdakarya

[5] Sudjana, Djuju. 2004. Pendidikan Nonformal: Wawasan, Sejarah Perkembangan, Filsafat \& Teori Pendukung, serta asas.Bandung:Falah Production 